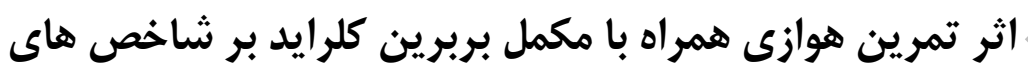

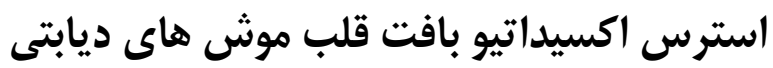

$$
\text { عقيل صديقى'، احمد عبدى*'، محمدعلى آذربايجانى'، على رضا برارى' }
$$

() كروه فيزيولوثى ورزشى، ولحد آيت الهه آملى، دانشكاه آزاد اسلامى، آما،، ايران

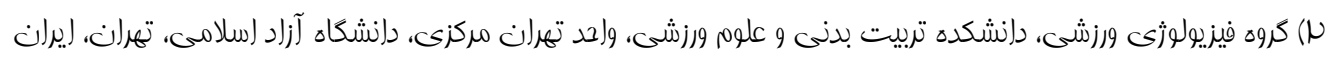

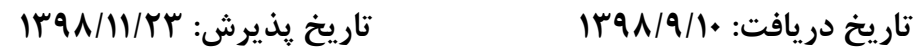

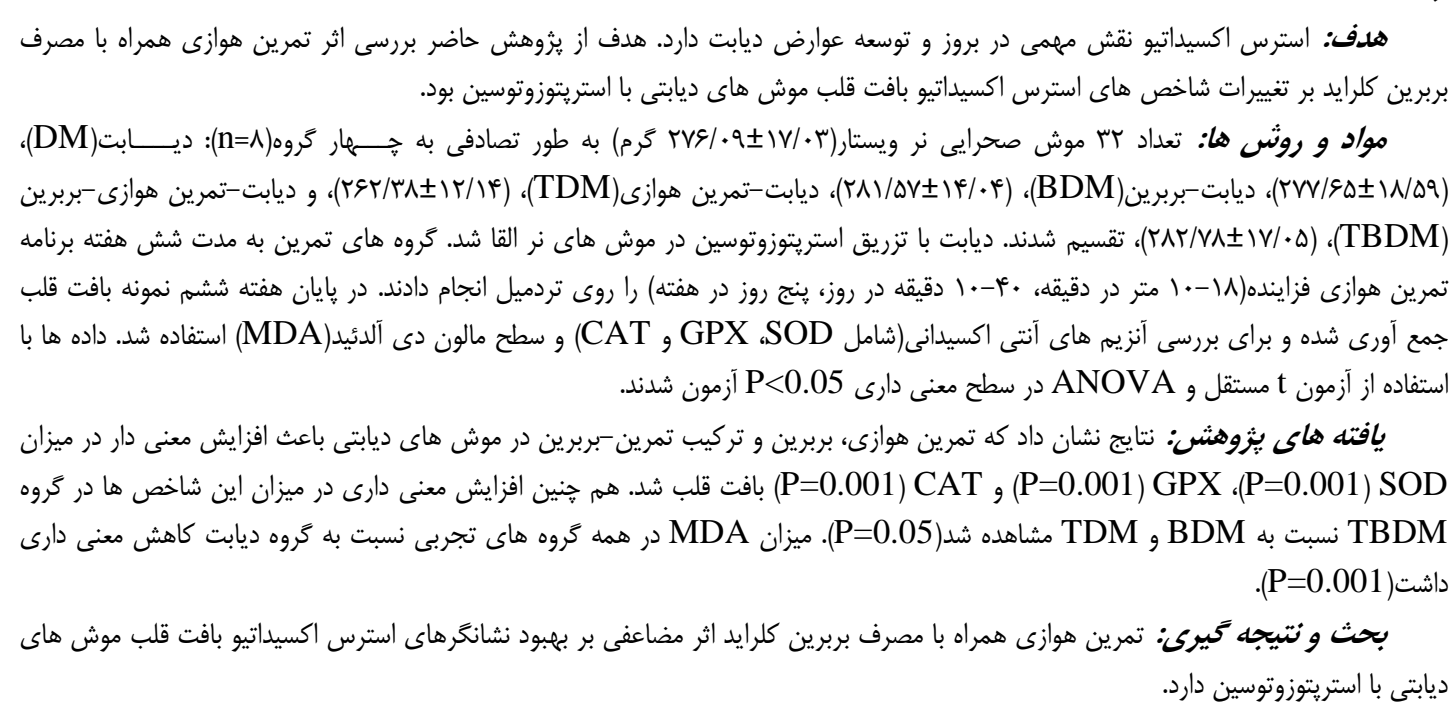

$$
\text { وازه هاى كليدى: فعاليت ورزشى، بربرين كلرايد، ديابت، استرس اكسيداتيو }
$$

Email:a.abdi58@gmail.com

* نويسنده مسئول: گروه فيزيولوزى ورزشى، واحد آيت الله آملى، دانشخاه آزاد اسلامى، آمل، ايران

Copyright (C) 2019 Journal of Ilam University of Medical Science. This is an open-access article distributed under the terms of the Creative Commons Attribution international 4.0 International License (https://creativecommons.org/licenses/by-nc/4.0/) which permits copy and redistribute the material, in any medium or format, provided the original work is properly cited. 


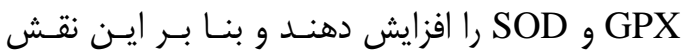

مهمى در تعادل ردوكس درون سلولى ايفا مى كنند(ه). علاوه بر اين نشان داده شده كه ديابت با افزايش سطح

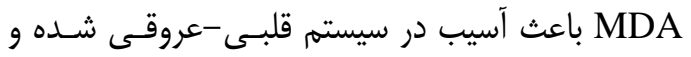
فعاليت هاى ورزشى با كاهش سطح MAD بافت قلب

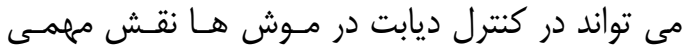

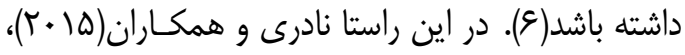

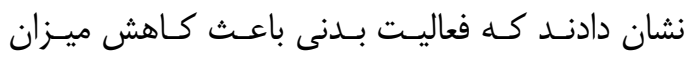
و و افزايش SODA و SPX و CAT بافت قلب در

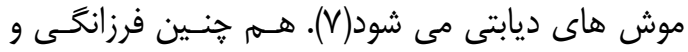

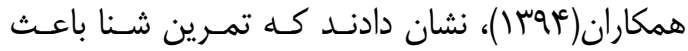
افزايش سطح CAT و SOD و كماهش

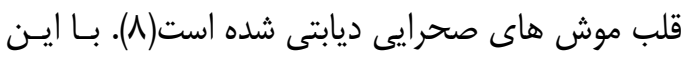

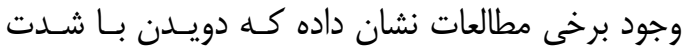

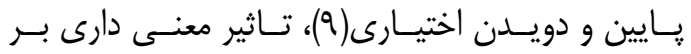

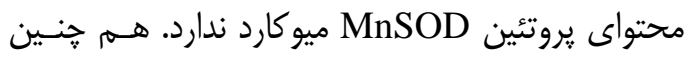

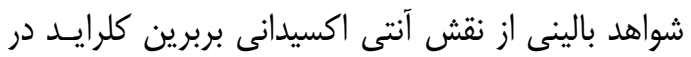

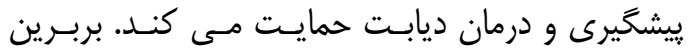
كلرايد يكى از مكمل هاى مفيد مى باشـــ كـه از گيــاه

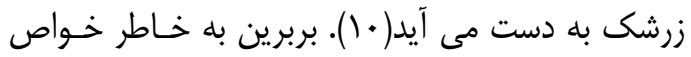

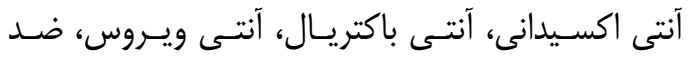

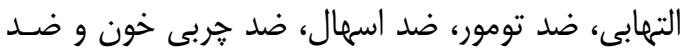

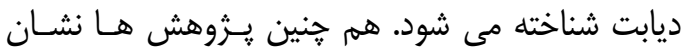

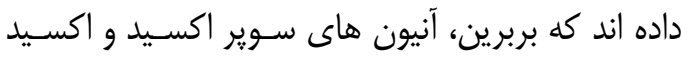

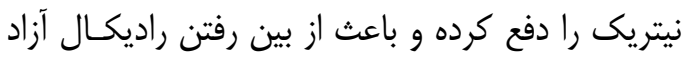
NO مى شود. هم جنين بربرين باعث جلوگيرى توليـد

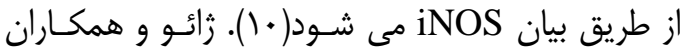

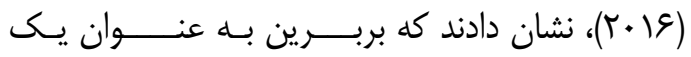

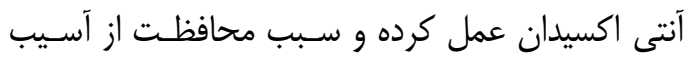

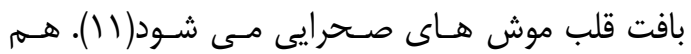

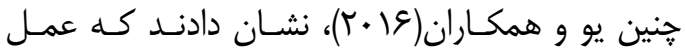
محافظتى بربرين بر بافت قلب موش هاى صـار صحرايى از

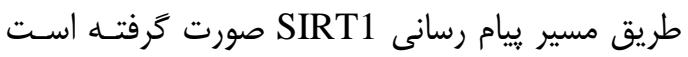

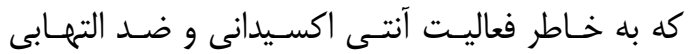
بربرين بوده است(I)). با وجود ييشـرفت هـاى كـهـ در

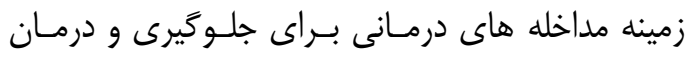

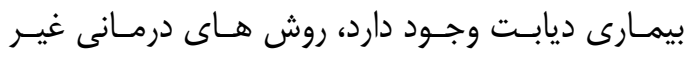

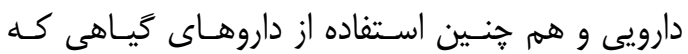

مقدمه

ديابت يك اختلال متابوليكى اسـت كـه عمـــاً بـاــا افزايش سطح قندخون و عوارض عروقى همراه بـوده و

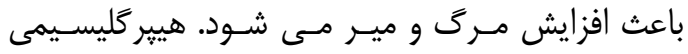

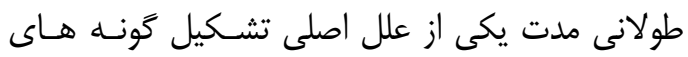

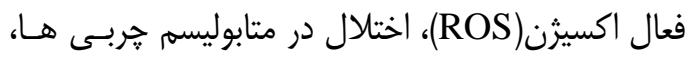

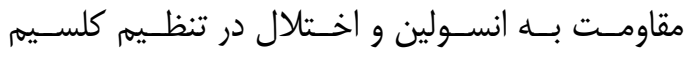

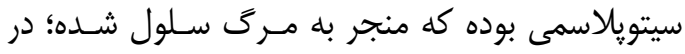
نتيجه نارسايى هاى قلبى ايجـاد مسى كنــ(1). مقــادير

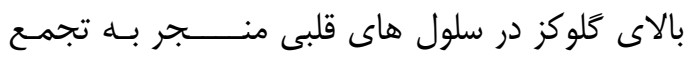
كونه هاى فعال اكسيثن در سلول هاى عضله قلب شده

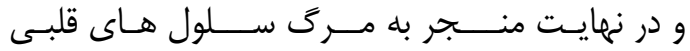

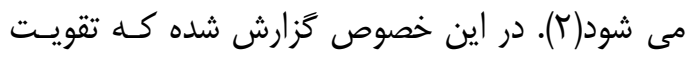

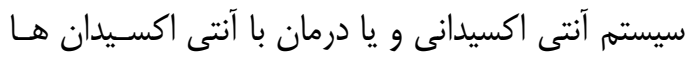

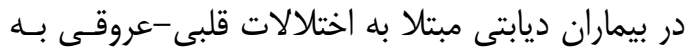

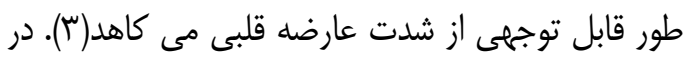

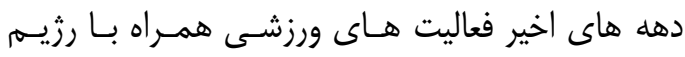

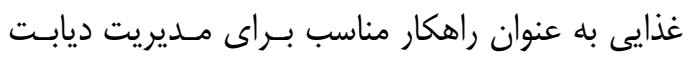

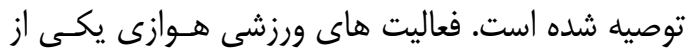
بهترين مداخله غير دارويى در كنترل قندخون مى باشد.

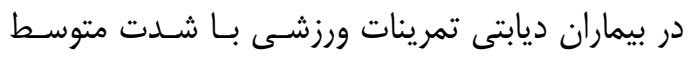
براى بهتر شدن شرايط متابوليكى ييشنهاد شــده اسـت.

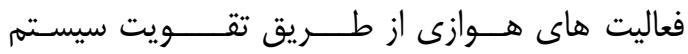

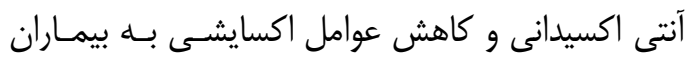

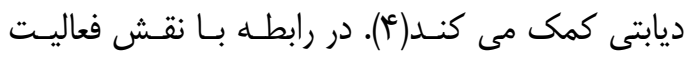

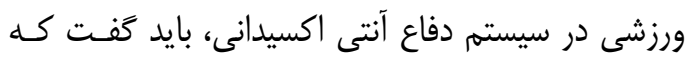
فعاليت ورزشى منجر به افزايش حجم اكسيثن مصرفى، تغييـرات در هموسـتاز كلسـيم داخـل سـلول، تغييـرات

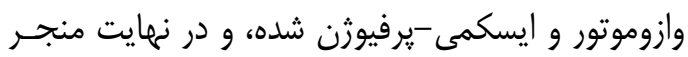

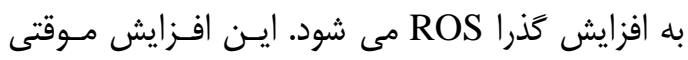
مذكور در توليد ROS، در طولانى مدت منجر به ايجاد

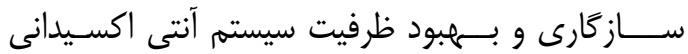

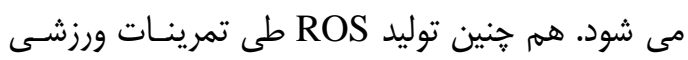

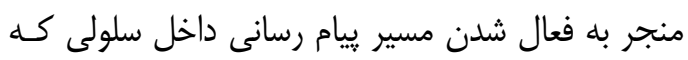
حساس به استرس اكسيداتيو هستند، مانتـد مسـيرهاى

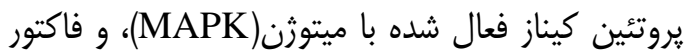

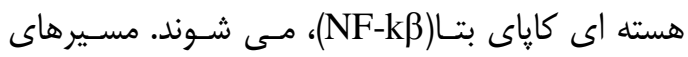

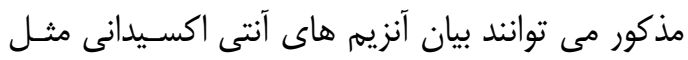


ديابت با تزريق تـك دوز mg/kg •ع استريتوزوتوسـين

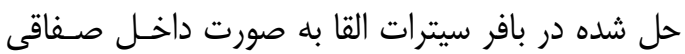
صورت كرفت. براى تشخيص ديابتى بودن موش هـاى داى

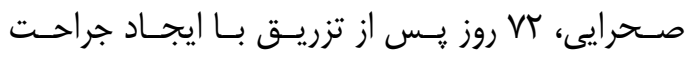
كوجى توسط لانست در دم حيوان يك قطره خون بـر

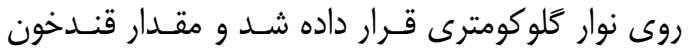

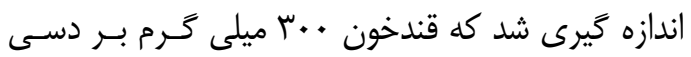

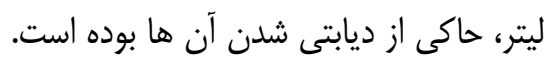

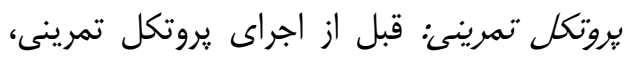

تمامى حيوانات به مدت يكى هفته با نحوه انجام فعاليت

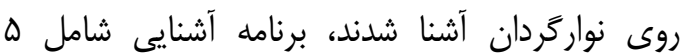
جلسه راه رفتن و دويدن با سرعت ه تا م متر در دقيقه و شيب صفر درصد و به مدت ^ تا ـا ـ دقيقه بود. شدت تمرين از طريق سرعت تردميل كنترل گرديد. گروه ها به لحاظ آمادگى اوليه(VO2

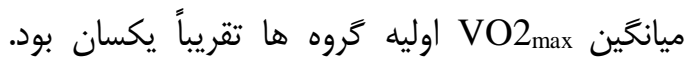

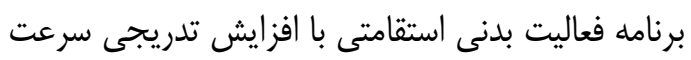

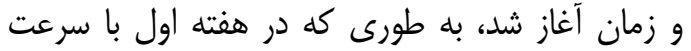

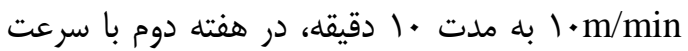
1·m/min

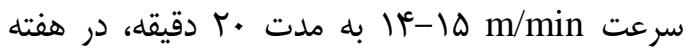

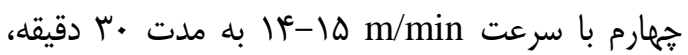

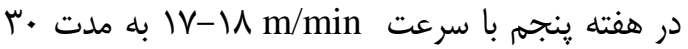

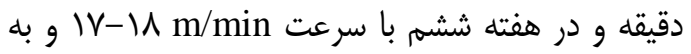

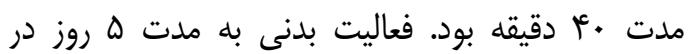
هفته بوده و در ابتدا و انتهاى هر جلسه تمرين، س دقيقه

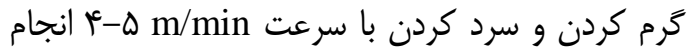

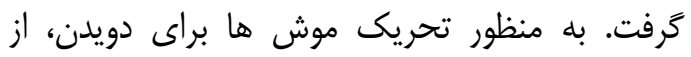

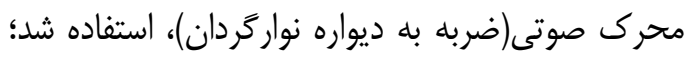
بدين صورت كه در جلسات اول، از محرك الكتريكى با ولتاز كم، همراه با محرك صوتى استفاده شد و پِ از از

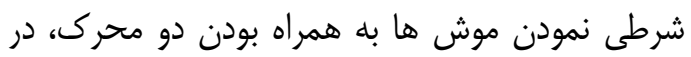

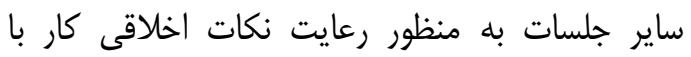
حيوان آزمايشخاهى، فقط از محرك صوتى استفاده

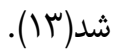
روش اندازه كيرى VO2

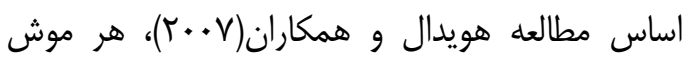
ابتدا به مدت • ا دقيقه با شدت • ا متر در دقيقه مرحله
نسبت به داروهاى شيميايى اثرات جانبى كمتـرى دارد، مورد توجه قرار كرفته است. از طرف ديخـر نشـان داده

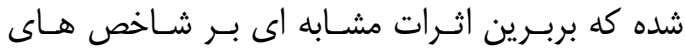

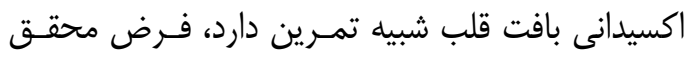

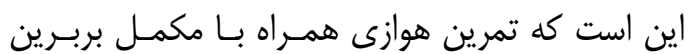
كلرايد اثر بهترى نسبت به هر كدام به تنهايى بـر ايسن

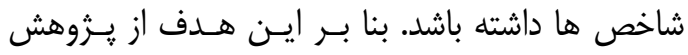

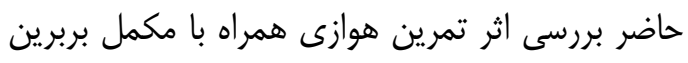
كلرايد بر بيان برخى شاخص هاى اسـترس اكسـيداتيو بافت قلب رت هاى ديابتى مى باشد.

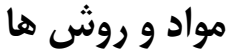

اين يزوهش از نوع تجربى بوده و همه آزمايش هاى هاى

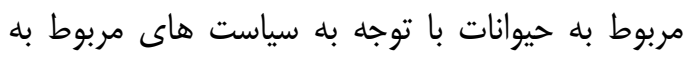
حمايت از حيوانات(بر اساس خط مشى هاى تراس قرارداد هلسينگى) انجام شد و قوانين راهنماى انستيتوى ملى حلى انى

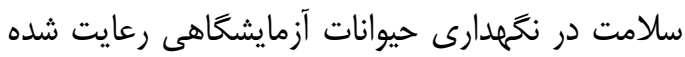

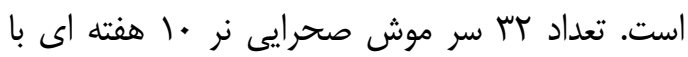

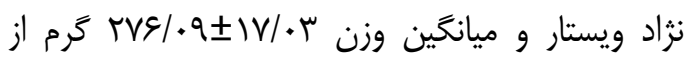
انستيتو קاستور تهيه شد و به آزمايشگاه جانورشناسى يرديس بين الملل دانشكاه علوم يزشكى يزد منتقل

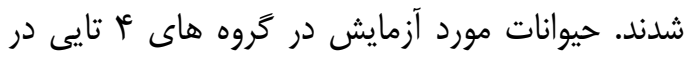

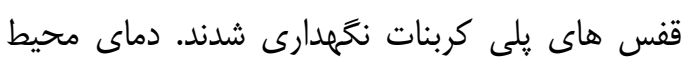

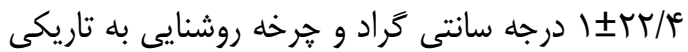

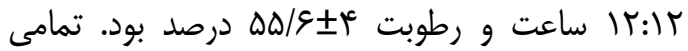
حيوانات به آب و غذاى ويزه موش دسترسى آزاد رطاد

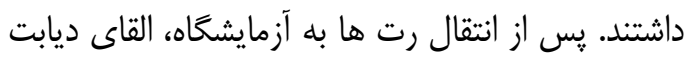

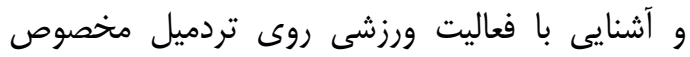
جوندكان، به طور تصادفى به جهار گروه تقسيم شدند. كروه هاى مورد مطالعه در اين يزوهش شامل: ديابت

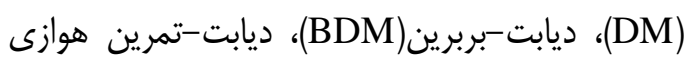

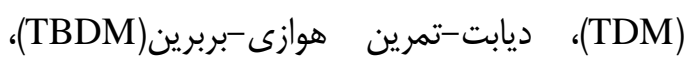
بودند. موش صحرايى گروه هاى تمرين، يك برنامه

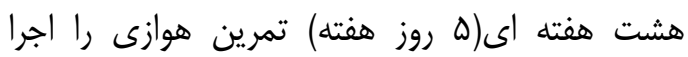

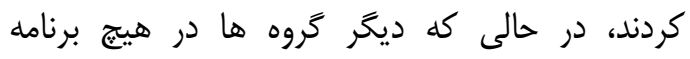
تمرينى شر كت داده نشدند.

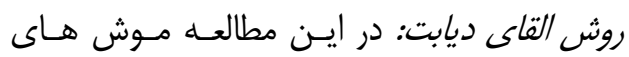

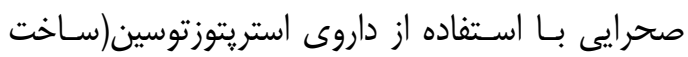

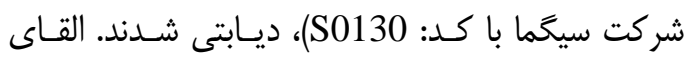


تحليل آمارى: از آمار توصيفى براى دسته بندى

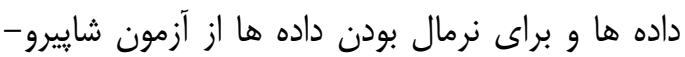

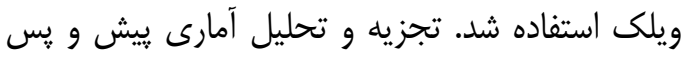

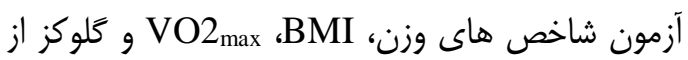

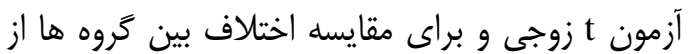

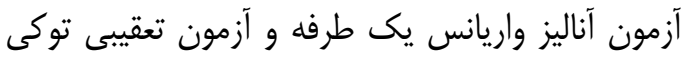

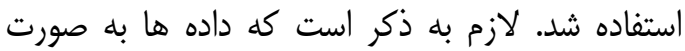

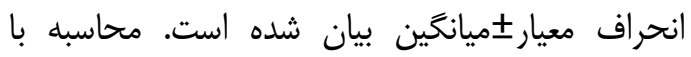

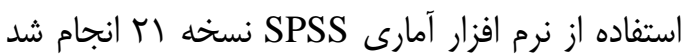

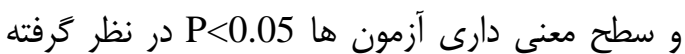

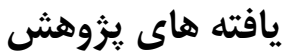

در جدول شـــماره ا ميانخين و نـــتايج آزمون درون گروهى و بين گروهى مربوط به متغيرهاى يزوهش در گروه هاى مختلف ارائه شده، و در جدول دران شماره r نيز نتايج آزمون تعقيبى مربوط به به متغيرهاى

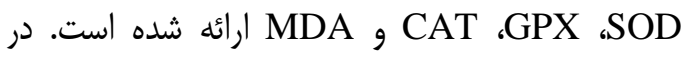
نمودارهاى شماره ا تأ نيز تغييرات سطوح متغيرهاى

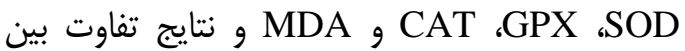
كروهى اين متغيرها آورده شده است. تجزيه و و تحليل

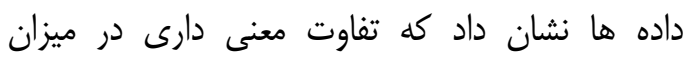
تغييرات SOD بافت قلب بين گروه هاى مختلف وجود داشت(F=36.134, P=0.001)(جدول شماره (). نتايج

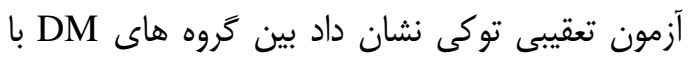
TBDM و (P=0.001) TDM ، (P=0.001) BDM (P=0.001)، تفاوت معنى دارى وجود دارد. هم جنين بين تروه TBDM با PDM (P=0.001)، و TDM (P=0.029)، اختلاف معنى دارى مشاهده شد(جدول

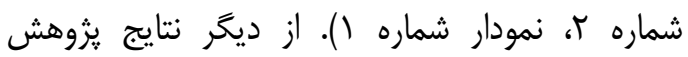
حاضر، تفاوت معنى دار در تغييرات GPX بافت قلب لثارد بين كروه ها بود(F=10.094, P=0.001)(جدول شماره (). نتايج آزمون تعقيبى توكى نشان داد بين

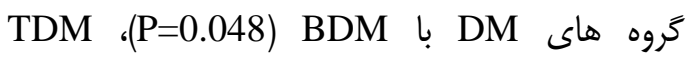

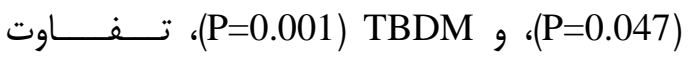
معنى دارى وجود دارد. هم حنين بين گروه TBDM با

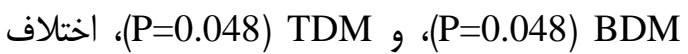
معنى دارى مشاهده شد(جدول شماره ז، نمودار شماره
كرم كردن را سيرى مى كردند، سيس آزمون فزاينده

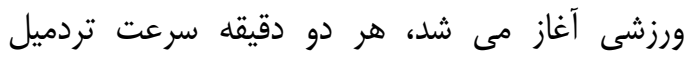

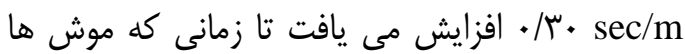

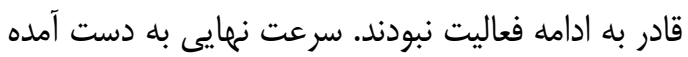

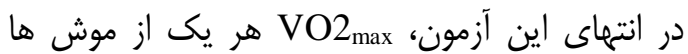
بود(1) (1). روش محاسبه شاخــص توده بلنى(BMI) در موش ها: بعد از وزن كشى موش ها داند در هر مرحله،

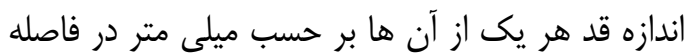

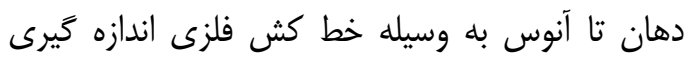
شده و مقدار BMI هر كدام ثبت شد. نحوه تهيه و مصرف بربرين كلرايد: مكمل مورد

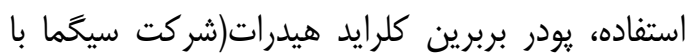

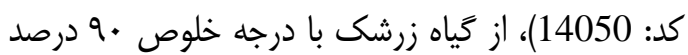

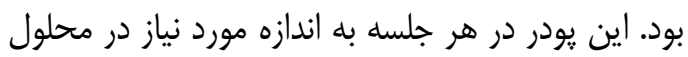

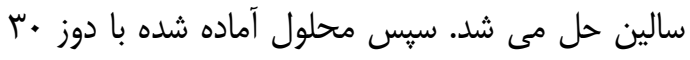

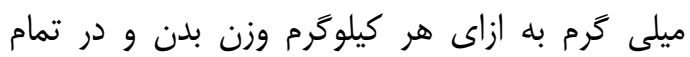

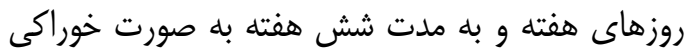

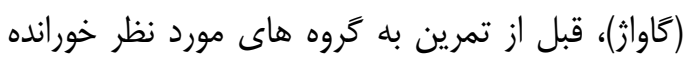

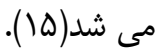
روش نمونه كيرى بافت: يس إز اعمال متغير

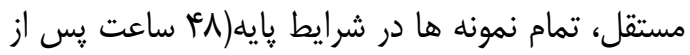

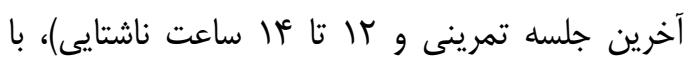
قطع نخاع كردن بى هوش شدند. بعد از بـ هـ هوشى،

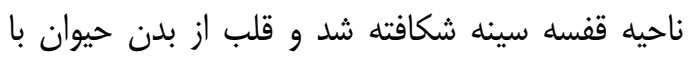
دقت جدا كرديد و بلافاصله يس از جداسازى و شست و و

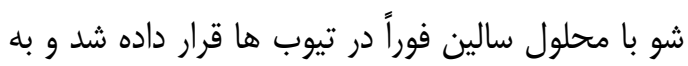

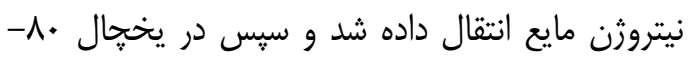

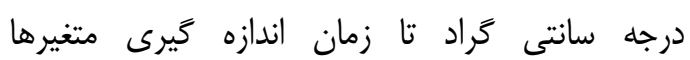
نخهدارى شد. غلظت بافتى GPX، CAT، SOD و و به روش الايزا با استفاده از كيت هاى مخصوص موش هــاى صحســرايى(شركت ZellBio جmbH حساسيت اندازه گيرى به ترتيب براى GPX، U/mL

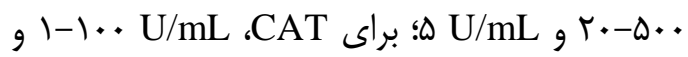

و $ه-1 . . \mathrm{U} / \mathrm{mL}$ ،SOD

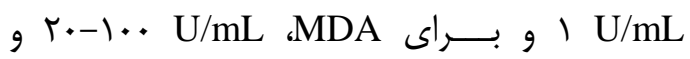

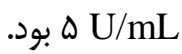


آمارى نشان داد كه تفاوت معنى دارى در ميزان تغييرات MDA بافت قلب گروه هاى مختلف وجود دارد(F=83.086, P=0.001)(جدول شماره ()). نتايج

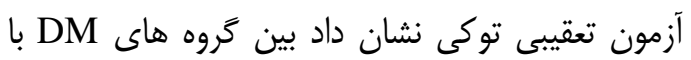
TBDM و (P=0.001) TDM (P=0.001) BDM (P=0.001)، تفاوت معنى دارى وجود دارد. هم جنين

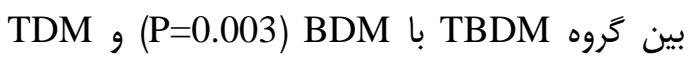
(P=0.049)، اختلاف معنى دارى مشاهده شد(جدول

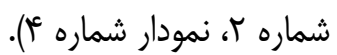

r). علاوه بر اين نتايج يثوهش حاضر نشان دهنده

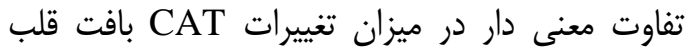

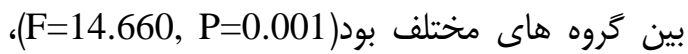
(جدول شماره (). نتايج آزمون تعقيبى توكى نشان دود داد

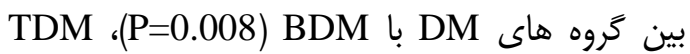
(P=0.001) TBDM و (P=0.002)

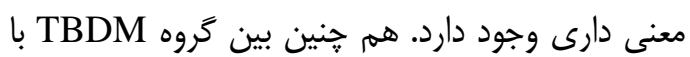
(ج=0.023) BDM

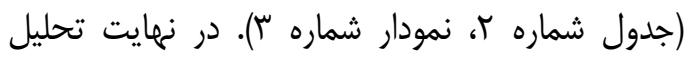

جدول شماره ا. نتايج آمار توصيفى و استنباطى مربوط به متغيرهاى يزوهش دئش

\begin{tabular}{|c|c|c|c|c|c|c|}
\hline p بين كروهى p & $\begin{array}{c}\text { ديابت-تمرين-بربرين }(\mathrm{n}=\Lambda)(\mathrm{TBDM})\end{array}$ & $\begin{array}{c}\text { ديابت-تمرين } \\
(\mathrm{n}=\wedge) \text { (TDM) }\end{array}$ & $\begin{array}{c}\text { ديابت-بربرين } \\
(\mathrm{n}=\Lambda)(\mathrm{BDM})\end{array}$ & $\begin{array}{c}\text { ديابت } \\
(\mathrm{n}=\Lambda)(\mathrm{DM})\end{array}$ & 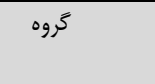 & متغير اندازه گيرى شده \\
\hline \multirow{3}{*}{ 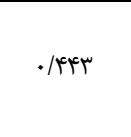 } & TAT/VAVII/.D & $T G T / K \Lambda \pm I T / I F$ & $r \Lambda|/ \Delta V \pm| F / \cdot r$ & $T W / 9 \Delta \pm 1 N / \Delta Q$ & ييشآزمون & \multirow{3}{*}{ 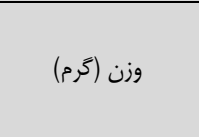 } \\
\hline & $r r / / V E \pm T I / . G$ & $r \mid N / \Delta \Lambda \pm r r / \cdot \Delta$ & 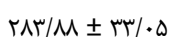 & TrE/TY \pm TV/V. & يس آزمون & \\
\hline & /..r r* &.$/ .4 \mathrm{~V} *$ & $. / r \mid *$ &.$/ . .1 *$ & p درون گروهى p p & \\
\hline \multirow{3}{*}{.$/ 14}$. & $.|q| \varepsilon \pm . / .4 V$ & $. / \Delta V G \pm . / .+\Lambda$ & T & $. / Q 1 N \pm . / .4 t$ & ييش آزمون & \multirow{3}{*}{$*$ BMI $\left(\mathrm{Kg} / \mathrm{m}^{2}\right)$} \\
\hline &. $\mid \leftarrow \varepsilon \cdot \pm \cdot / . r \Delta$ & $\cdot|\leftarrow \wedge \mu \pm \cdot / \cdot \wedge|$ & $\cdot / 0 \cdot V \pm \cdot / \cdot r q$ & سץ.|• & مِس آزمون & \\
\hline & $.1 . .1 *$ &.$/ 14 r$ & $\%$ / r * & $.1 . .1 *$ & p درون گروهى p & \\
\hline \multirow{3}{*}{$\beta \cdot / \cdot .1$} & $r \cdot / / f \pm 1 / 9 \Delta$ & $r \cdot \pm r / r$. & $14 \pm 1 / .9$ & $r \cdot / r \Delta \pm r / q \Delta$ & ييش آزمون & \multirow{3}{*}{$\mathrm{VO} 2$ max } \\
\hline & $r g / T \cdot \pm 1 / v \Lambda$ & $r \varphi \pm r / q 1$ & $I V / T \Delta \pm 1 / 9 q$ & $1 \varepsilon / 0 \cdot \pm r / q V$ & يسآزمون & \\
\hline &.$/ .+1 *$ & $.1 . .1 *$ &.$/ .+1 *$ &.$/ . .1 *$ & p درون گروهى p p & \\
\hline \multirow{3}{*}{$\beta \cdot / . r r$} & $\Delta I V \pm 9 \Delta / \Delta \&$ & DrI/GT \pm 11. & $\Delta r \cdot / / r \pm 111 /$. & $\Delta M Y / G T \pm \Lambda 1 / G K$ & بيشآزمون & \multirow{3}{*}{ كلوكز)(mg.dl) } \\
\hline & $\mu \Lambda F / \Delta \cdot \pm \Lambda r / g V$ & $F \cdot T / G T \pm \Delta F / T \Lambda$ & $r \Lambda \Delta / \Delta \cdot \pm r \cdot / \cdot r$ & $\Delta V T / \cdot . \pm \Delta r / V r$ & يسآزمون & \\
\hline & $\cdot / \cdot 1 *$ &.$/ . r \Delta *$ &.$/ .11 *$ & .1 .91 & ا & \\
\hline$\beta \cdot / \cdot \cdot 1$ & $r / r \Delta \pm . / q 1$ & $T / L T \pm \cdot / / V$ & $r / \Lambda) \pm \cdot / T^{\circ} V$ & $1 /{ }^{*} \Delta \pm \cdot / \kappa \Lambda$ & \multicolumn{2}{|c|}{ SOD activity $(\mathrm{U} / \mathrm{ml})$} \\
\hline$\beta \cdot / \cdot .1$ & $r \cdot / \Lambda \cdot \pm N / r$ & $r e / \kappa q \pm \Delta / / F$ & $r \mu / \mu_{T} \pm r / \cdot V$ & $|q| \cdot V \pm r / q \mid$ & \multicolumn{2}{|c|}{ GPX activity (U/ml) } \\
\hline$\beta \cdot / \cdot \cdot 1$ & $\Gamma / \Delta \varepsilon \pm \cdot / \Lambda \varepsilon$ & $r / 9 \mid \pm \cdot / \Lambda$. & T/KTE $\cdot /$ AV & $1 / 1 \pm \cdot / \pi$ & \multicolumn{2}{|c|}{ Catalase activity $(\mathrm{U} / \mathrm{ml})$} \\
\hline$\beta \cdot / \cdot 1$ & $1 / V \Delta \pm \cdot / r V$ & $r / \cdot r \pm 1 / \cdot v$ & $r / \Delta \varphi \pm \cdot / q$. & $\Lambda / \Delta V \pm 1 / \Lambda \Delta$ & \multicolumn{2}{|c|}{$\operatorname{MDA}(\mathrm{U} / \mathrm{ml})$} \\
\hline
\end{tabular}

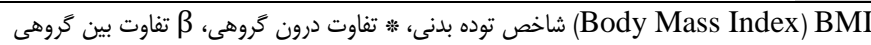


جدول شماره r. نتايج آزمون تعقيبى مربوط به متغيرهاى MDA CAT ،GPX SOD،

\begin{tabular}{|c|c|c|c|c|}
\hline $\mathrm{P}$ & تفاوت ميانكين ها & كروه مقايسه شونده & 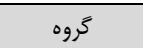 & 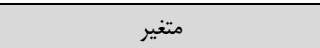 \\
\hline.$/ .1 *$ & $-1 / \% \Delta \Lambda$ & ديابتى-بربرين & & \\
\hline.$/ . \cdot 1 *$ & $-1 / 9 V r$ & ديابتى -تمرين & 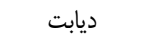 & \\
\hline.$/ . .1 *$ & $-r /$ Va & ديابتى -تمرين-بربرين & & \\
\hline . MFF & $-\cdot|9|$ & ديابتى-تمرين & ديابتى -بربرين & SOD activity \\
\hline $.1 .+1 *$ & $1 / 4 r q$ & ديابتى -تمرين-بربرين & & \\
\hline.$/ . r 9 *$ & ./ATA & ديابتى -تمرين-بربرين & ديابتى -تمرين & \\
\hline.$/ \vdash \wedge *$ & $-V / \mu q V$ & ديابتى-بربرين & & \\
\hline $.1 . F \mathrm{~F} *$ & $-V / \widetilde{R r}$ & ديابتى -تمرين & 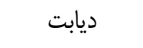 & \\
\hline $.1 . \cdot 1 *$ & $-1 F / V T \Delta$ & ديابتى -تمرين-بربرين & & GPX activity (U/ml) \\
\hline $1 / \cdots$ & $-\cdot 1 \cdot \cdot 9$ & ديابتى -تمرين & ديابتى -بربرين & \\
\hline$\cdot / \cdot \uparrow \wedge *$ & $-V / r \omega$ & ديابتى -تمرين-بربرين & & \\
\hline.$/ . \uparrow$ ^ * & $-V / \pi \Delta$ & ديابتى -تمرين-بربرين & ديابتى -تمرين & \\
\hline$\%$ $/ \wedge_{*}$ & $-1 / \mu \cdot 9$ & ديابتى-بربرين & & \\
\hline.$/ . r *$ & $-1 / \Delta \cdot 1$ & ديابتى -تمرين & ديابت & \\
\hline.$/ .+1 *$ & $-r / F Y \Lambda$ & ديابتى -تمرين-بربرين & & Catalase activity $(\mathrm{U} / \mathrm{ml})$ \\
\hline.$/ 9 \Delta r$ & $-1 / 9 \Delta \Delta$ & ديابتى -تمرين & ديابتى -بربرين & \\
\hline /.rr* & $-1 / 1 f$ & ديابتى -تمرين-بربرين & & \\
\hline $.1 \cdot V \Delta$ &.$- / 9198$ & ديابتى -تمرين-بربرين & ديابتى -تمرين & \\
\hline$\cdot / \cdot+1 *$ & $\Delta / \cdots r$ & ديابتى-بربرين & & \\
\hline.$/ . .1 *$ & D/DFT & ديابتى -تمرين & 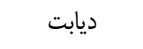 & \\
\hline.$/ .+1 *$ & $9 / 8 \mid \Lambda$ & ديابتى -تمرين-بربرين & & )MDA (U/ml \\
\hline - $/ 9 \Delta F$ & $\cdot / D F$ & ديابتى -تمرين & ديابتى -بربرين & \\
\hline$\cdot / \cdot r^{*}$ & $-1 / \wedge \mid r$ & ديابتى -تمرين-بربرين & & \\
\hline $.1 .49 *$ & $-1 / T V T$ & ديابتى -تمرين-بربرين & ديابتى -تمرين & \\
\hline
\end{tabular}

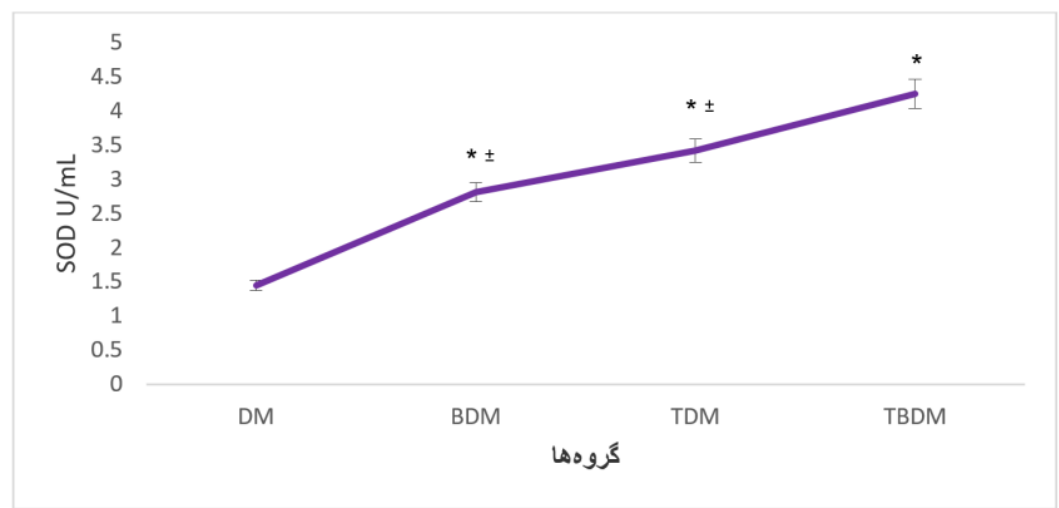

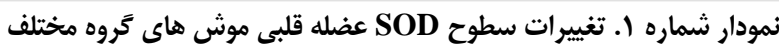

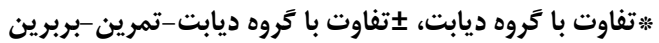

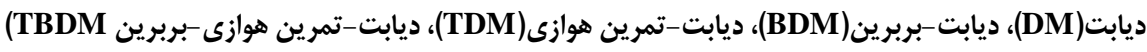




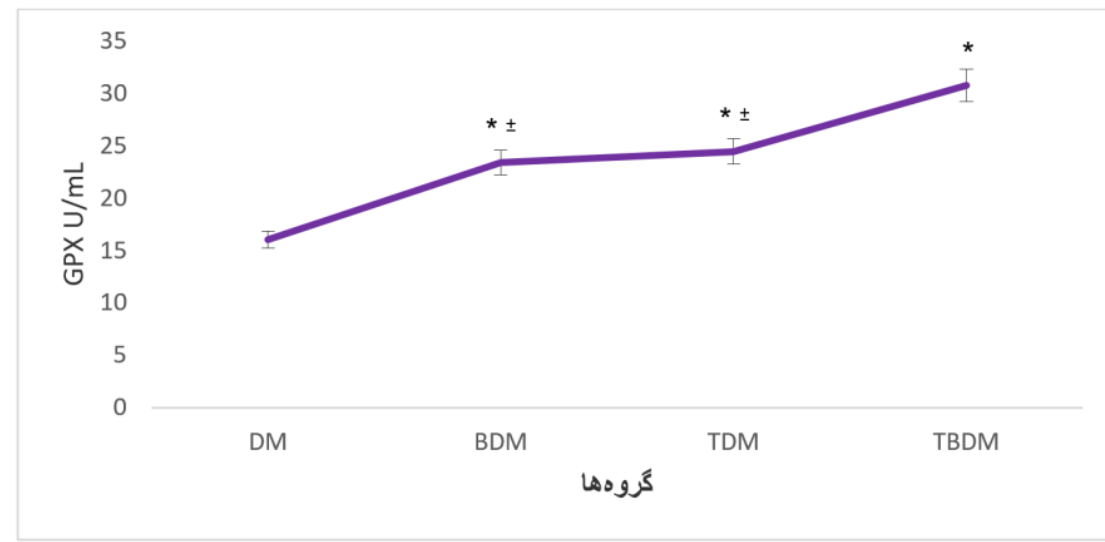

نمودار شماره r. تغييرات سطوح GPX عضله قلبى موش هاى تروه مختلف

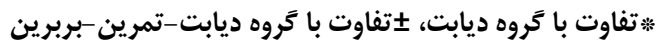

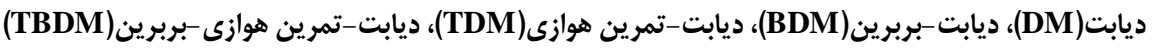

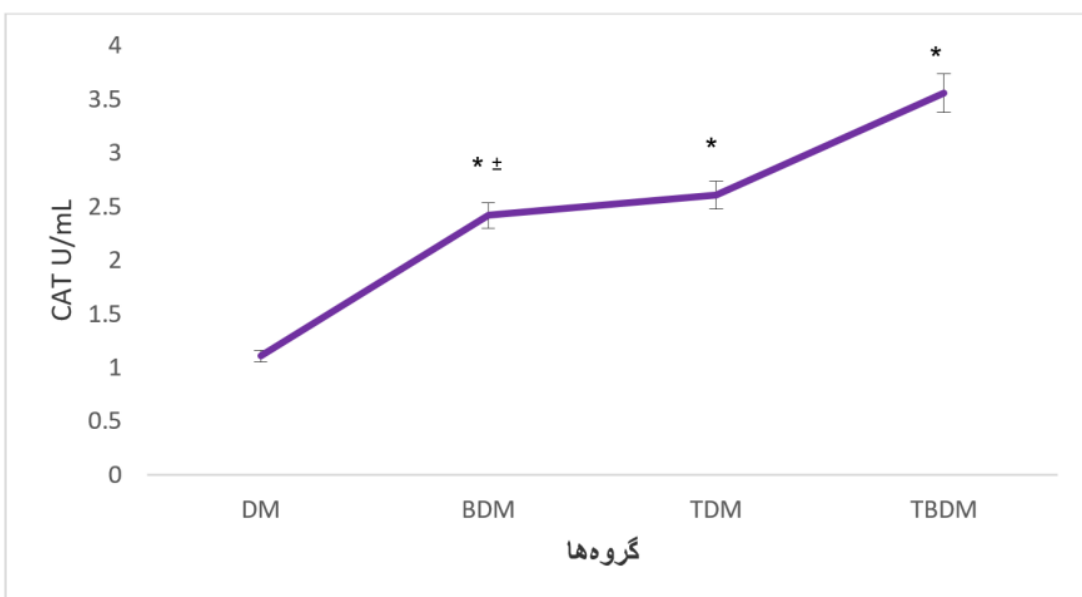

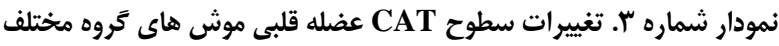

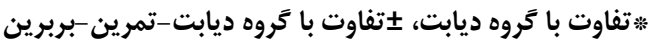

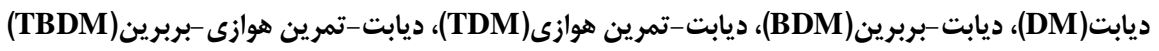

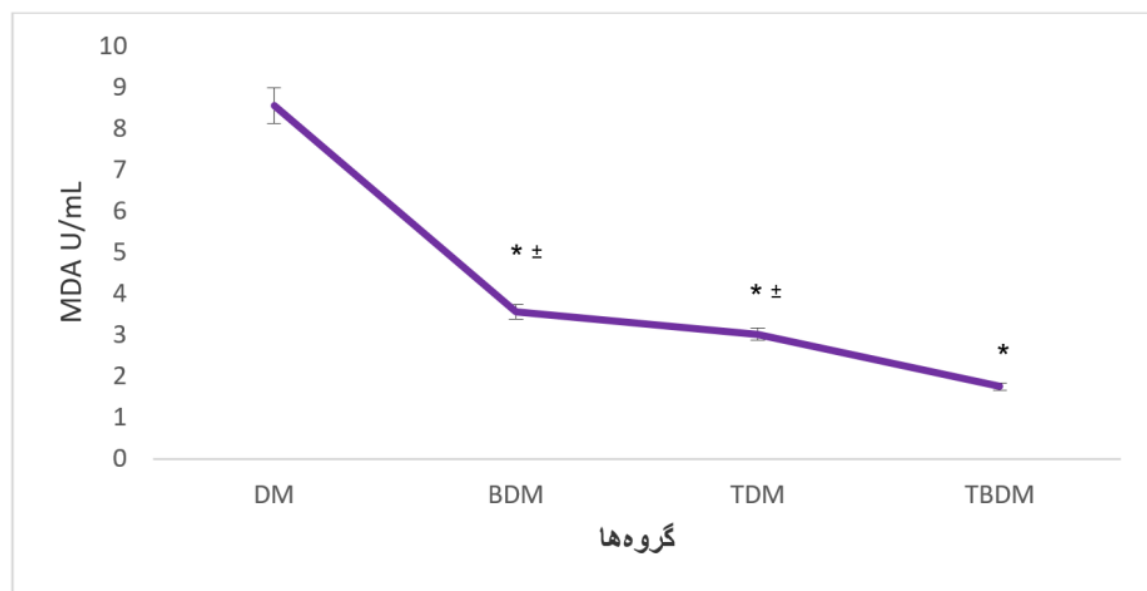

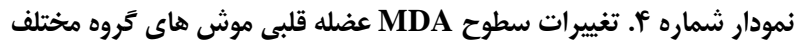

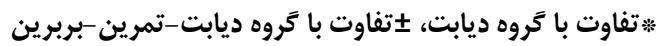

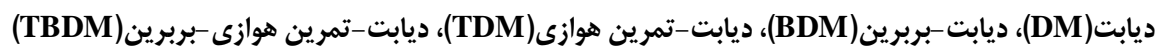


دقيق بهبود فعاليت SOD، و GPX SAT در نتيجه فعاليت ورزشى مشخص نيست، جندين مكانيزم براى توضيح احتمالى وجود دارد. تحقيقات نشان داده اند كه

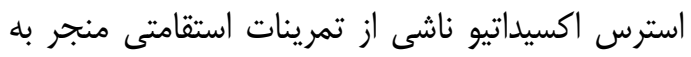

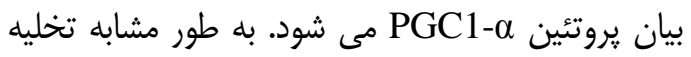
آنتى اكسيدان درون زاى كلوتاتيون نيز موجب افزايش بيان PGC1- در نتيجه تمرينات استقامتى مى شود. PGC1- $\alpha$

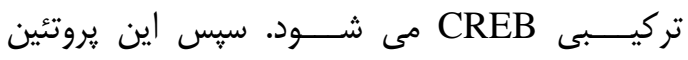

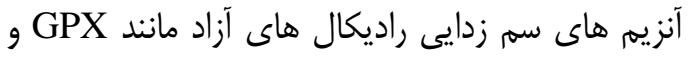

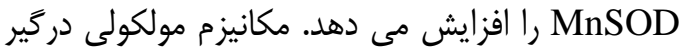

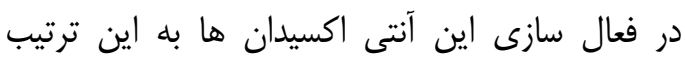

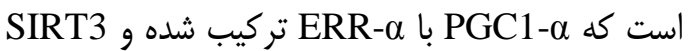
در ماتريكس ميتوكندرى را فعال مى كند. SIRT3 تنظيم كننده توليد ROS از طريق اتصال و داستيله

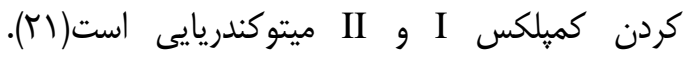
مطالعات ييشين نشان داده اند كه SIRT3 قادر به داستيله كردن آنزيم ميتوكندريايى MnSOD است و

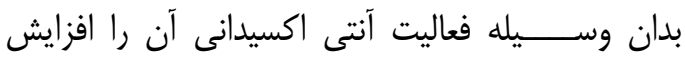
مى دهد، بنا بر اين به نظـــر مى رسد

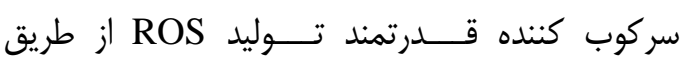
بيان آنتى اكسيدان ها است(آل). در مقابل بيان بيش از حد طريق افزايش بيان MnSOD و افزايش فعاليت آنزيم كاتالاز مى شود. علاوه بر اين م-ه- PGC1 بيان بروتئين جفت نشده ucp2 و ucp3 را افزايش داده و در نتيجه

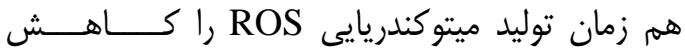

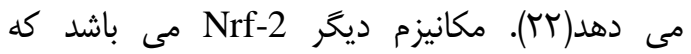

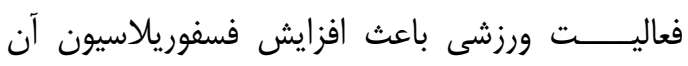
مى شود(سٓ). بنا بر اين فعال شدن Nrf-2 در نتيجه فعاليت ورزشى مكانيزم محافظتى اكسيدانى را با اتصال

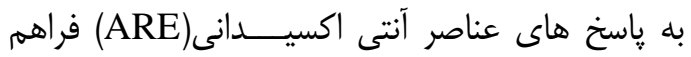
مى كند كه در يروموتور جندين آنزيم آنتى اكسيدانى از إنى جمله MnSOD وجود دارد. علاوه بر اين تمرينات ورزشى باعث افزايش SIRT1 شده كه باعث افزايش فعاليت سيستم آنتى اكسيدانى(توسط MnSOD و و

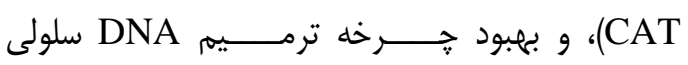

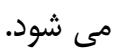

\section{بحث و نتيجلكيرى}

نتايج يزوهش حاضر نشان داد كه تمرين هوازى باعث كــاهش استرس اكســيداتيو بافت قلب در موش هاى صحرايى ديابتى با STZ شده است. در اين

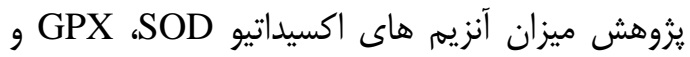
ارزيابى شد. مطالعات نشان مى دهد كه القاى ديابت در موش هاى صحر ايى با افزايش سطح و كاهش فعاليت آنزيم هاى اكسيداتيو همراه بوده و فعاليت هاى ورزشى مى تواند اين روند را معكوس إنس كند(V). نتيجه مطالعه حاضر نشان دهنده اثر محافظتى تمرين هوازى بر استـــرس اكســيداتيو بافت قلب دهات موش هاى صحر ايى ديابتى مى باشد.

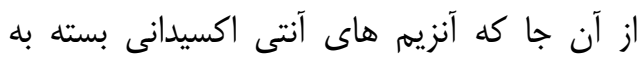
استرس اكسيداتيو وارد شده روى بافت خاص و هم هنين ظرفيت دفاعى آنتى اكسيدانى ذاتى، در حين فعاليت هاى ورزشى به صورت انتخابى فعال شوند، اطلاعات متضادى در مورد ارتباط بين فعاليت هاى

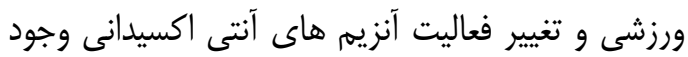

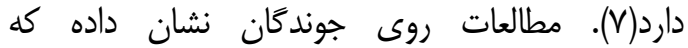
سازكارى ناشى از تمرينات ورزشى باعث تقويت فعاليت

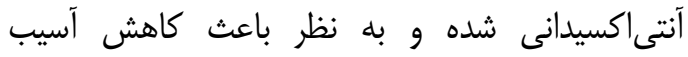

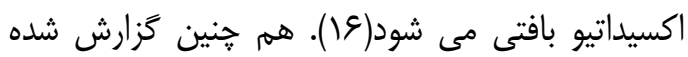
كه سطح آنتى اكسيدان ميوكارد در نتيجه فعاليت ورزشى در موش هاى ديابتى(V) بهبود مى يابد. هم جنين برخى شواهد نشان مى دهد فعاليت ورزشى

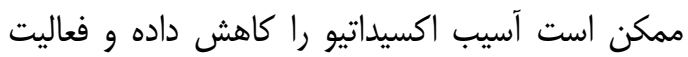
آنزيم هاى آنتى اكسيدانى را در انواع مختلف بافت الت الت الت

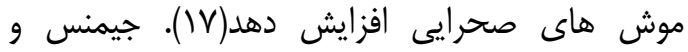

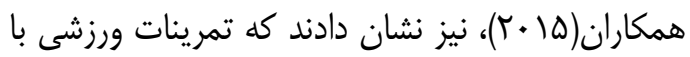
شدت كم باعث بهبود استرس اكسيداتيو بافت قلب موش هاى صحرايى ديابتى مى شود(1)). در مقابل

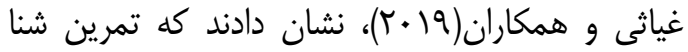

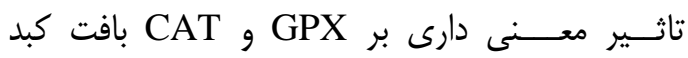
موش هاى صحرايى ديابتى ندارد(19). هم تُنين

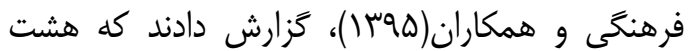
هفته تمرين ورزشى استقامتى بر مقادير SOD و بافت قلب موش هاى صحر ايیى ديابتى تاثير نداشته و

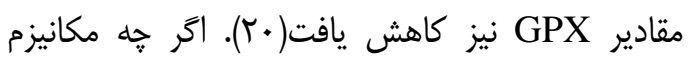


داشت. به نظر مى رسد اثر هم زمان تمرين هوازى و مصرف بربرين كلرايد بر شاخص هاى استرس اكسيداتيو در بافت قلب بررسى نشده است. با اين وجود

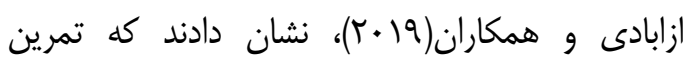
همراه با مصرف بربرين كلرايد باعث كاهش MAD و مخان افزايش سطح SOD و CAT مخحه موش هاى مسموم شده با ديازينون شد(·ץ). هم جنين قياسى و

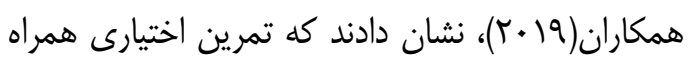

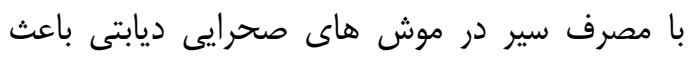
بهبود ساختار و عملكرد آنتى كسيدانى بافت قلب شافي دانى

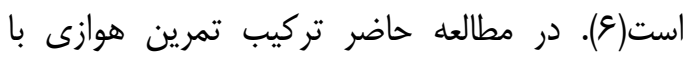

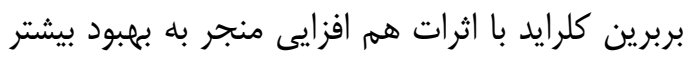

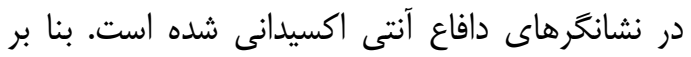

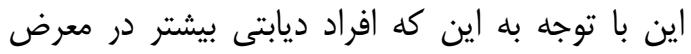

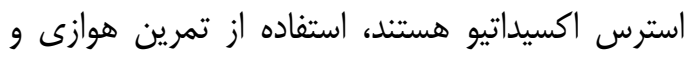
مصرف بربرين مى تواند باعث بهبود يراكسيداسيون

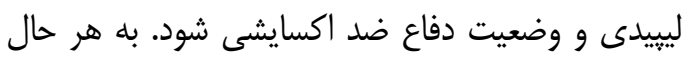
مكانيزم سلولى اثر تمرين هوازى و بربرين بر ديابت به

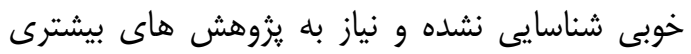

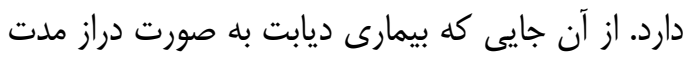

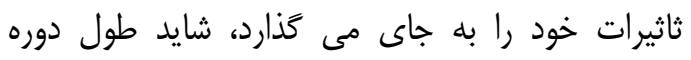
يزوهش در تحقيق حاضر از محدوديت هاى مهم ديكر براى بررسى دقيق اثرات اين بيمارى بر استرس

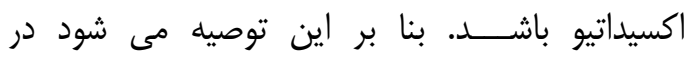
يروتكل هاى بعدى از دوره هاى طولانى تر استفاده

نتايج يزوهش حاضر نشان داد كه فعاليت ورزشى

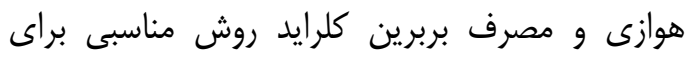

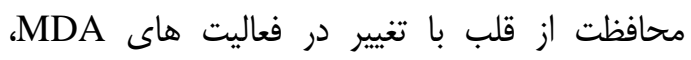
CAT و CAX ،SOD زمان تمرين و مصرف بربرين كلرايد بيشتر بود. بنا بر باري اين تركيب اين دو با اثر هم افزايى كه دارند برين ابزار

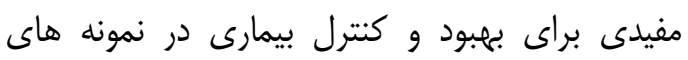
مبتلا به ديابت مى باشد.

\section{سياسكزارى}

اين تحقيق با تاييد كميته اخلاق در يزوهش هاى

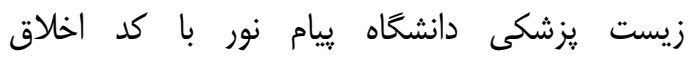

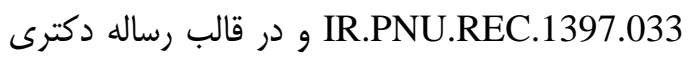

از ديخر نتايج يزوهش حاضر كاهش ميزان MDA

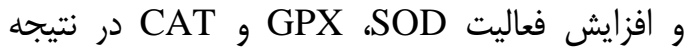
مصرف بربرين كلرايد در موش هاى ديابتى بود.

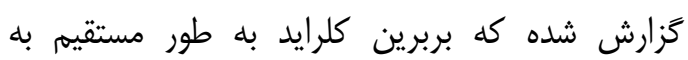

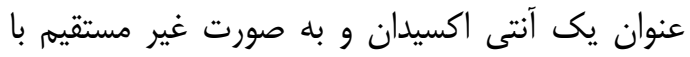
خنثى كردن راديكال هاى آزاد و افزايش توليد SOD كبر و GSH CAT GPX اكسيداتيو محافظت مى كند(بآ). مطالعات قبلى نشان

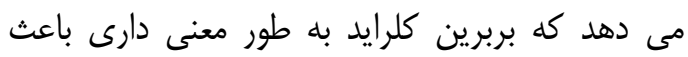

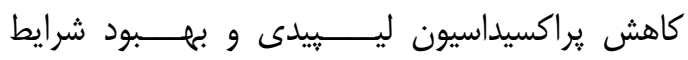

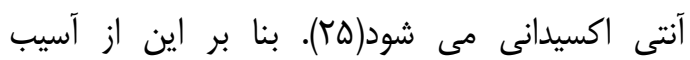

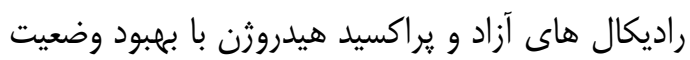

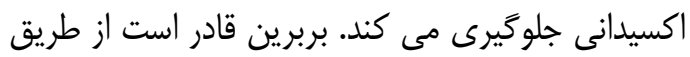

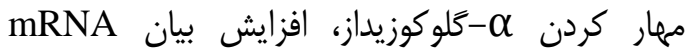

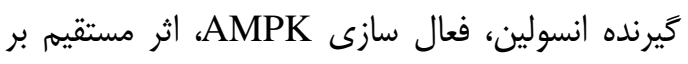

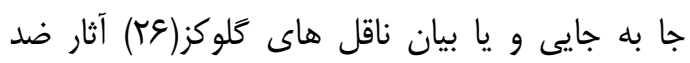

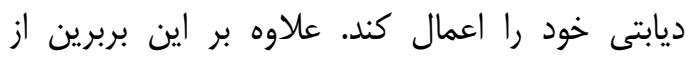
تخريب سلول هاى يانكراس به ويزه سلول هاى م در مقابل استرس اكسيداتيو در موش هاى صحر ايیى ديابتى

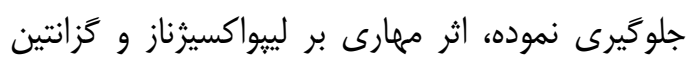

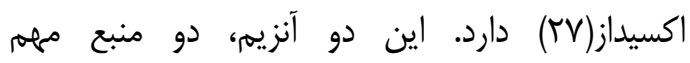

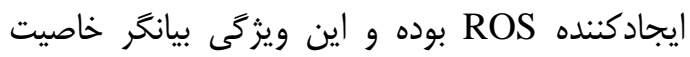

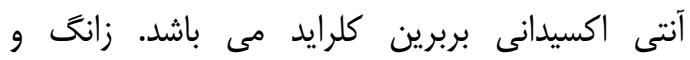

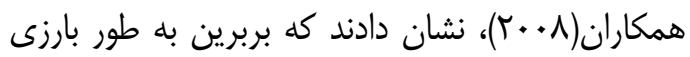

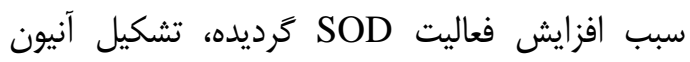
سوير اكسيد و MDA را در موش هاى صحر ايى كاهش فرالبت

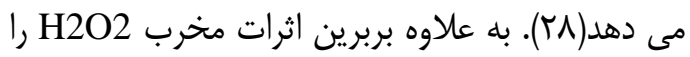

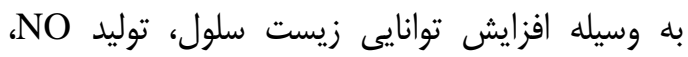
فعال سازى SOD و كاهش آزادسازى لاكتيك اسيد

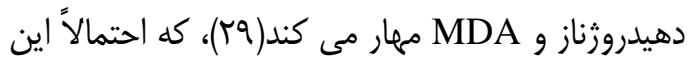
مكانيزم ها سبب كنترل استرس اكسيداتيو و در نتيجه كاهش عوارض مخرب راديكال هاى آزاد ناشى از

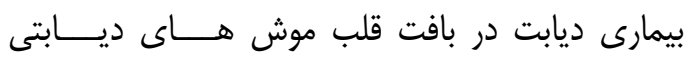
مى شود.

در مورد اثر هم زمان تمرين هوازى با بربرين

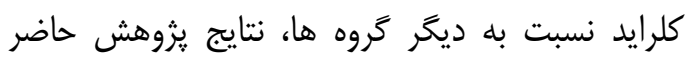
نشان داد كه در موش هاى صحرايى ديابتى سطوح و و GPX ، SOD 


$$
\text { قـى دارند. }
$$

\section{Reference}

1.Farag YM, Gaballa MR. Diabesity an overview of a rising epidemic. Nephrol Dial Transplant 2011;26:28-35.

doi.10.1093/ndt/gfq576.

2.Liu Q, Wang S, Cai L. Diabetic cardiomyopathy and its mechanisms: role of oxidative stress and damage. J Diabetes Investig 2014;5:623-34.

doi.10.1111/jdi.12250.

3.Wang J, Song Y, Elsherif L, Song Z, Zhou G, Prabhu SD, et al. Cardiac metallothionein induction plays the major role in the prevention of diabetic cardiomyopathy by zinc supplementation. Circulation 2006; 113:544-54. doi:10.1161/circulationaha.105.537894.

4.Abdi A, Ramezani N, Abbasidaloie A, Ganji N. [The effect of aerobic training and coriandrum sativum extract on some oxidative stress factors in male diabetic wistar Rats]. Tabari J Prev Med 2017; 2:3443. (Persian).

5.Ji L, Gomez M, Steinhafel N, Vina J. Acute exercise activates nuclear factor NF$\kappa \mathrm{B}$ signaling pathway in rat skeletal muscle. FASEB J 2004;18:1499-506. doi.10.1096/fj.04-1846com.

6.Ghyasi R, Mohaddes G, Naderi R. Combination effect of voluntary exercise and garlic (Allium sativum) on oxidative stress, cholesterol level and histopathology of heart tissue in type 1 diabetic Rats. J Cardiovasc Thorac Res 2019;11:61. doi.10.15171/jevtr.2019.10.

7.Naderi R, Mohaddes G, Mohammadi M, Ghaznavi R, Ghyasi R, Vatankhah AM. Voluntary exercise protects heart from oxidative stress in diabetic Rats. Adv Pharm Bull 2015;5:231. d doi.10.15171/apb.2015.032.

8.Farzanegi P, Habibian M, Anvari SM. [Effect of swimming training and arbutin supplement on cardiac antioxidant enzymes and oxidative stress in diabetic Rats]. J Gorgan Uni Med Sci 2015;17:39-45. (Persian)

9.Judge S, Jang YM, Smith A, Selman C, Phillips T, Speakman JR, et al. Exercise by lifelong voluntary wheel running reduces subsarcolemmal and interfibrillar
در دانشعاه آزاد اسلامى واحد آيــت الله آملى

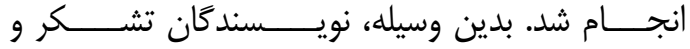

mitochondrial hydrogen peroxide production in the heart. Am J Physiol Reg Int Comp Physiol 2005;289: 1564-72. doi.10.1152/ajpregu.00396.2005.

10.Kazaz IO, Mentese A, Demir S, Kerimoglu G, Colak F, Bodur A, et al. Berberine inhibits the ischemia-reperfusion induced testicular injury through decreasing oxidative stress. Am J Eme Med 2020;38:33-37. doi.10.1016/j.ajem.2019.04.001. 11.Zhao GL, Yu LM, Gao WL, Duan WX, Jiang B, Liu XD, et al. Berberine protects rat heart from ischemia/reperfusion injury via activating JAK2/STAT3 signaling and attenuating endoplasmic reticulum stress. Acta Pharmacol Sin 2016;37:354-67. doi.10.1038/aps.2015.136.

12.Yu L, Li Q, Yu B, Yang Y, Jin Z, Duan $\mathrm{W}$, et al. Berberine attenuates myocardial ischemia/reperfusion injury by reducing oxidative stress and inflammation response: role of silent information regulator 1. Oxid Med Cell Long 2016;2016:1689602. doi.10.1155/2016/1689602.

13.Seo H, Park CH, Choi S, Kim W, Jeon $\mathrm{BD}$, Ryu S. Effects of voluntary exercise on apoptosis and cortisol after chronic restraint stress in mice. J Exerc Nutrition Biochem 2016;20:16. doi.10.20463/jenb.2016.09.20.3.3. 14.Høydal MA, Wisloff U, Kemi OJ, Ellingsen O. Running speed and maximal oxygen uptake in rats and mice: practical implications for exercise training. Eur J Cardiovasc Prev Rehabil 2007;14:753-60. doi: 10.1097/HJR.0b013e3281eacef1.

15.Mahmoud AM, Abdelrahman MM, Bastawy NA, Eissa HM. Modulatory effect of berberine on adipose tissue PPAR $\gamma$, adipocytokines and oxidative stress in high fat diet/streptozotocin-induced diabetic Rats. JAPS 2017;7: $\quad-10$. doi.10.7324/JAPS.2017.70401.

16.Servais S, Couturier K, Koubi H, Rouanet J, Desplanches D, Sornay M, et al. Effect of voluntary exercise on $\mathrm{H} 2 \mathrm{O} 2$ release by subsarcolemmal and intermyofibrillar mitochondria. Free Rad 
Biol Med 2003;35:24-32. doi.10.1016/s0891-5849(03)00177-1.

17.Leeuwenburgh C, Hansen PA, Holloszy $\mathrm{JO}$, Heinecke JW. Oxidized amino acids in the urine of aging rats: potential markers for assessing oxidative stress in vivo. Am J Physiol 1999;276: 128-35. doi: 10.1152/ajpregu.

18.Gimenes C, Gimenes R, Rosa C, Xavier N, Campos D, Fernandes A, et al. Low intensity physical exercise attenuates cardiac remodeling and myocardial oxidative stress and dysfunction in diabetic rats. J Diabetes Res 2015; 2015:457848. doi.10.1155/2015/457848.

19.Ghiasi R, Naderi R, Mozaffar A, Alihemmati A. The effect of swimming training on oxidative stress SIRT1 gene expression and histopathology of hepatic tissue in type 2 diabetic Rats. Biol Futura 2019;

70:167-74. doi.10.1556/019.70.2019.21.

20.Farhangi N, Nazem F, Zehsaz F. [Effect of endurance exercise on antioxidant enzyme activities and lipid peroxidation in the heart of the streptozotocin induced diabetic Rats]. JSSU 2017;24:798-809. (Persian)

21.Heyat F. [Cellular and Molecular Mechanisms of the production of free radicals during exercise and their function on skeletal muscles]. J Fasa Uni Med Sci 2017;7:1-11. (Persian)

22.Steinbacher P, Eckl P. Impact of oxidative stress on exercising skeletal muscle. Biomolecules 2015;5:356-77. doi.10.3390/biom5020356.

23.Toborek M, Seelbach MJ, Rashid CS, András IE, Chen L, Park $\mathrm{M}$, et al. Voluntary exercise protects against methamphetamine induced oxidative stress in brain microvasculature and disruption of the blood brain barrier. Mole Neurodegener 2013; $\quad$ 8:22. doi.10.1186/1750-1326-8-22.
24.Kulkarni SK, Dhir A. Possible involvement of L-arginine-nitric oxide cyclic guanosine monophosphate signaling pathway in the antidepressant activity of berberine chloride. Eur $\mathrm{J}$ Pharmacol 2007;569:77-83.

doi.10.1016/j.ejphar.2007.05.002.

25.Ju H, Li X, Zhao B, Han Z, Xin W. Scavenging effect of berbamine on active oxygen radicals in phorbol ester stimulated human polymorphonuclear leukocytes. Biochem Pharmacol 1990;39:1673-8. doi.10.1016/0006-2952(90)90110-7.

26.Kong WJ, Zhang H, Song DQ, Xue R, Zhao W, Wei J, et al. Berberine reduces insulin resistance through protein kinase $\mathrm{C}-$ dependent up regulation of insulin receptor expression. Metabolism 2009;58:109-19. doi.10.1016/j.metabol.2008.08.013.

27. Sharma B, Salunke R, Balomajumder C, Daniel S, Roy P. Anti-diabetic potential of alkaloid rich fraction from Capparis decidua on diabetic mice. $\mathbf{J}$ Ethnopharmacol 2010;127:457-62.

doi.10.1016/j.jep.2009.10.013.

28.Zhang X, Ren H, Liu L. Effects of different dose berberine on hemodynamic parameters and $\mathrm{Ca} 2+\mathrm{i}$ of cardiac myocytes of diastolic heart failure Rat model. Zhong Yao Za Zhi 2008;33:818-21.

29.Tan Y, Tang Q, HU Br, Xiang JZ. Antioxidant properties of berberine on cultured rabbit corpus cavernosum smooth muscle cells injured by hydrogen peroxide 1. Acta Pharmacol Sin 2007;28:1914-8. doi.10.1111/j.1745-7254.2007. 00705.x

30.Ezabadi A, Peeri M, Azarbayjani MA, Hosseini SA. The effects of resistance training and berberine chloride supplementation on oxidative stress markers in the cerebellum tissue of diazinon poisoned Rats. Middle East J Rehabil Health Stud20013; 6: 92870. doi.10.5812/mejrh.92870. 


\title{
Effect of Aerobic Training and Berberine Chloride Supplementation on Oxidative Stress Indices in the Heart Tissue of Streptozotocin- Induced Diabetic Rats
}

\author{
Sadighi $A^{l}$, Abdi $A^{* 1}$, Azarbayjani $M^{2}$, Barari $A^{l}$ \\ (Received: December 01, 2019 \\ Accepted: 12 February 2020)
}

\begin{abstract}
Introduction: Oxidative stress plays a key role in the onset and development of diabetes complications. This study aimed to investigate the effect of aerobic training with berberine chloride on indices changes of oxidative stress in the heart tissue of streptozotocin-induced diabetic rats.
\end{abstract}

Materials \& Methods: In total, 32 male Wistar rats $(276.09 \pm 17.03)$ were randomly divided into four groups of eight per group, including Diabetes (DM) (277.65 \pm 18.59$)$, Diabetes-Berberine (BDM) $(281.57 \pm 14.04)$, Diabetes-Aerobic Training (TDM) (262.38 \pm 12.14$)$, and Diabetes-Aerobic Training-Berberine (TBDM) $(282.78 \pm 17.05)$. Diabetes was induced by the injection of streptozotocin in male rats. The training groups performed a progressive aerobic running program (10$18 \mathrm{~m} / \mathrm{min}, \quad 10-40 \mathrm{~min} /$ day, and 5 days/week) on a motor-driven treadmill for six weeks. At the end of the six ${ }^{\text {th }}$ week, heart tissue specimens were collected and used for the determination of antioxidant enzymes (e.g., SOD, GPX, and CAT) and Malondialdehyde (MDA) level. The data were analyzed using independent t-test and ANOVA. A p-value less than 0.05 was considered statistically significant. Ethics code: IR.PNU.REC.1397.033

Findings: The results showed that aerobic training, berberine, and exercise-berberine combination significantly increased SOD $(\mathrm{P}=0.001), \quad$ GPX $\quad(\mathrm{P}=0.000)$, and CAT $(\mathrm{P}=0.001)$ of the heart tissue in diabetic rats. Moreover, a significant increase was observed in these indices in the TBDM group, compared to the BDM and TDM groups $(\mathrm{P}<0.05)$. The MDA level in all experimental groups was significantly lower than that in the diabetic group $(\mathrm{P}=0.001)$.

Discussions \& Conclusions: Aerobic training combined with berberine chloride has remarkable interactive effects on the improvement of oxidative stress markers in the heart tissue of streptozotocin-induced diabetic rats.

Keywords: Berberine chloride, Diabetes, Exercise, Oxidative stress

1. Dept of Exercise Physiology, Ayatollah Amoli Branch, Islamic Azad University, Amol, Iran

2. Dept of Exercise Physiology, Faculty of Physical Education and Sports Science, Central Tehran Branch, Islamic Azad University, Tehran, Iran

*Corresponding author Email: a.abdi58@gmail.com

Scientific Journal of Ilam University of Medical Sciences 